\title{
Experimental study of lightweight concrete used for the production of canoe
}

\author{
Dr. Eethar Thanon Dawood*
}

* Department of Building and Construction Engineering, Technical College of Mosul, Mosul-Iraq.

*.Email : eethar2005@yahoo.com

\begin{abstract}
This study was conducted to investigate the properties of lightweight concrete produced by the inclusions of polystyrene beads and perlite that can be used for production of Canoe. Different percentages of polystyrene $(20,35,50$ and $65 \%)$ were used. Besides, the $50 \%$ of polystyrene beds with different percentages of perlite $(10,20,30,40,50$ and $60 \%)$ as partial replacement of sand were used. The fresh density, compressive strength, flexural strength and absorption capacity of the mixes were tested. The results show that the uses of $50 \%$ of polystyrene with $50 \%$ of perlite as partial replacement of sand exhibit suitable ranges of density, compressive and flexural strengths of lightweight concrete used for canoe production. Thus, the Canoe produced from these inclusions of polystyrene and perlite show a clear success in terms of floating.
\end{abstract}

Keywords: Concrete Canoe, Lightweight concrete, Perlite, Polystyrene.

$$
\begin{aligned}
& \text { در اسة تجريبية للخرسانة الخفيفة الوزن المستخدمة في صناعة القوارب الخرسانية }
\end{aligned}
$$

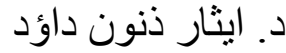

$$
\begin{aligned}
& \text { دكتور اه هندسة مدنية ـمو اد الإنشاء ألثاء } \\
& \text { رئيس قسم هندسة تقنيات البناء والإنشاءاتـ الكلية التقنية في الموصل } \\
& \text { الخلاصة المنان }
\end{aligned}
$$

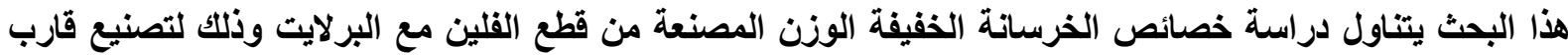

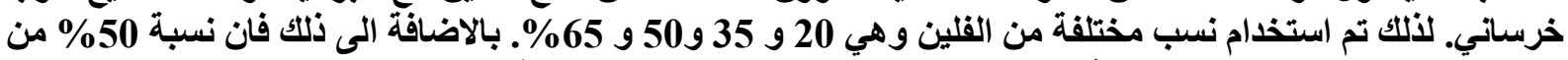

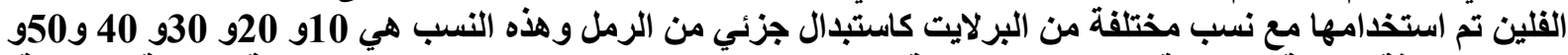

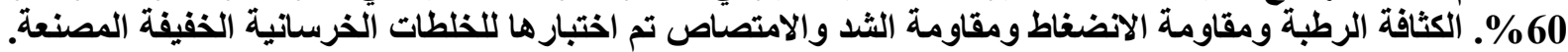

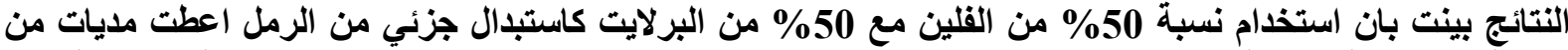

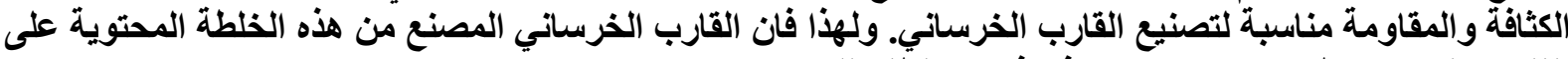

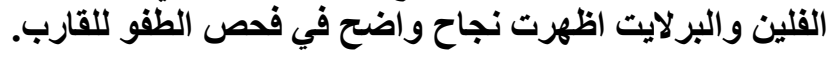




\section{Introduction}

Numerous researches have been carried out on natural or artificial lightweight aggregates in order to produce lightweight structural concrete. The objectives of mix design are to achieve desired workability, density and most importantly, the strength of concrete with the most economic proportions [1-5]. Expanded polystyrene waste in a granular form is used as a lightweight aggregate for production of lightweight structural concrete that float on water [6]. Polystyrene is a thermoplastic polymeric material initially in the solid form and it can be expanded by the use of steam and expansive agents [7]. By incorporating the polystyrene material for different volumes in the concrete, mortar or in the cement paste, a wide range of concrete densities can be produced [7-9].

On the other hand, expanded perlite can be used for manufacturing lightweight concrete [10]. This material, white or light grey in color, is about 1/10 the weight of sand or gravel. Perlite mixes with about $30 \%$ less water than comparable lightweight aggregates [11].

One of the applications of lightweight concrete is the manufacture of concrete canoe. Therefore, this study aimed to investigate using of different percentages of polystyrene as well as perlite as a partial replacement of sand to produce lightweight concrete with acceptable values of density and compressive strength. Such a concrete can be used for manufacturing of canoe.

\section{Materials and experimental}

\section{1. Materials}

Ordinary Portland cement used in this study was manufactured by Badush factory and it conforms to Iraqi standard specifications (IQS 5:1984)[12] as shown in Tables 1 and 2. Normal sand which is called Kanhash sand, was used in this study, the fineness modulus and specific gravity of this sand were 2.7 and 2.63, respectively. The expanded polystyrene beads were obtained as raw materials from the commercial sources and these beads were small in diameter and hard. The beads were modified by boiling water to conform the expanded polystyrene beads. The diameter of such beads ranged from 1.5 to $3 \mathrm{~mm}$. The density of these beads was $15 \mathrm{~kg} / \mathrm{m}^{3}$.Besides, Perlite with specific gravity 2.2 and absorption $6.3 \%$ was used in this study. The max. aggregate size of perlite used in this study was $0.150 \mathrm{~mm}$. Waterproofing materials (Betek-Aquaset) was used for ensuring that the canoe would be protected against penetration of water into the canoe. Lastly, reinforcement mesh distributed of $13 \mathrm{~mm} \times$ $13 \mathrm{~mm}$ square mesh with $1.0 \mathrm{~mm}$ diameter was used for the canoe production.

\section{Table 1. Physical characteristics of Ordinary Portland cement.}

\begin{tabular}{|l|l|l|}
\hline Test & Results & IQS : 5/1984 \\
\hline Consistency & 0.25 & $0.24-0.32$ \\
\hline Initial setting time (minute) & 120 & Min. 45 minute \\
\hline Final setting time (minute) & 265 & Max. 600 minute \\
\hline Fineness, Blaine, $\mathrm{m}^{2} / \mathrm{kg}$ & 275 & Min. 230 \\
\hline
\end{tabular}


Table 2. Chemical properties of Ordinary Portland cement

\begin{tabular}{|l|l|l|}
\hline Constituent & Component of OPC (\%) & $\begin{array}{l}\text { Limits of } \\
\text { IQS : 5/1984 }\end{array}$ \\
\hline $\mathrm{SiO}_{2}$ & 21.31 & - \\
\hline $\mathrm{Al}_{2} \mathrm{O}_{3}$ & 5.89 & - \\
\hline $\mathrm{Fe}_{2} \mathrm{O}_{3}$ & 2.67 & - \\
\hline $\mathrm{CaO}$ & 62.2 & - \\
\hline $\mathrm{MgO}$ & 3.62 & $\leq 5 \%$ \\
\hline $\mathrm{SO}_{3}$ & 2.6 & $\leq 2.8 \%$ \\
\hline Loss of ignition & 1.59 & $\leq 4 \%$ \\
\hline Insoluble residue & 0.24 & $\leq 0.75 \%$ \\
\hline Free CaO & 1.74 & - \\
\hline $\mathrm{L.S.F.}$ & 0.8818 & - \\
\hline $\mathrm{C}_{3} \mathrm{~S}$ & 33.37 & - \\
\hline $\mathrm{C}_{2} \mathrm{~S}$ & 35.92 & - \\
\hline $\mathrm{C}_{3} \mathrm{~A}$ & 11.09 & - \\
\hline $\mathrm{C}_{4} \mathrm{AF}$ & 8.12 & - \\
\hline
\end{tabular}

\section{2 Experimental tests.}

In this study the maximum aggregate size for aggregate used in concrete is $4.75 \mathrm{~mm}$. Therefore, the specimens of $50 \mathrm{~mm}$ cubes were cast and tested for fresh density, absorption and compressive strength. The test was conducted according to ASTM C642[13] and ASTM C109[14], respectively. On the other hand, the flexural strength was conducted according to ASTM C348[15]. Thus, the prisms $40 \times 40 \times 160 \mathrm{~mm}$ were used for this test. The flow design for all mixes ranged from 100 to $110 \%$.

\section{Results and discussion}

The properties of lightweight concrete mixes produced by the inclusion of polystyrene beads are shown in this section. However, the optimum mix was selected for the production of canoe. Then, the canoe was produced to examine it for floating test.

\subsection{Density}

The results of densities obtained from different lightweight concrete mixes are shown in Table 3. The results showed that the concrete is much influenced by the use of polystyrene beads. Therefore, the density of concrete was reduced from $2345 \mathrm{~kg} / \mathrm{m}^{3}$ (Ref. mix) to $1200 \mathrm{~kg} / \mathrm{m}^{3}$. This is obviously related to the specific gravity of the polystyrene beads which affect the density of the concrete [6]. Fig.1 shows the relation between density of concrete and polystyrene percentage. The inclusions of perlite with $50 \%$ of polystyrene decreased the density to more extent. The reduction in density also attributed to the specific gravity of perlite $[8,12]$. Thus, the relationship between density of concrete and perlite inclusions with constant percent of polystyrene $50 \%$ is shown in Fig. 2 . 
Table 3. Mix proportion and values of fresh density

\begin{tabular}{|c|c|c|c|c|c|c|}
\hline \multirow{2}{*}{ Mix No. } & \multicolumn{3}{|c|}{ Mix Proportion } & $\begin{array}{c}\text { Perlite \% as partial } \\
\text { replacement of sand }\end{array}$ & Polystyrene \%* & $\begin{array}{c}\text { Fresh Density } \\
\mathrm{kg} / \mathrm{m}^{3}\end{array}$ \\
\cline { 2 - 7 } & Cement & Sand & w/c & --- & $\mathbf{0}$ & $\mathbf{2 3 4 5}$ \\
\hline P0 & $\mathbf{1}$ & $\mathbf{2 . 2 5}$ & $\mathbf{0 . 6}$ & ---- & $\mathbf{2 0}$ & $\mathbf{1 8 9 0}$ \\
\hline P1 & $\mathbf{1}$ & $\mathbf{2 . 2 5}$ & $\mathbf{0 . 6}$ & ---- & $\mathbf{3 5}$ & $\mathbf{1 6 4 0}$ \\
\hline P2 & $\mathbf{1}$ & $\mathbf{2 . 2 5}$ & $\mathbf{0 . 6}$ & ---- & $\mathbf{5 0}$ & $\mathbf{1 4 5 0}$ \\
\hline P3 & $\mathbf{1}$ & $\mathbf{2 . 2 5}$ & $\mathbf{0 . 6}$ & ---- & $\mathbf{6 5}$ & $\mathbf{1 2 0 0}$ \\
\hline P4 & $\mathbf{1}$ & $\mathbf{2 . 2 5}$ & $\mathbf{0 . 6}$ & $\mathbf{1 0}$ & $\mathbf{5 0}$ & $\mathbf{1 3 6 0}$ \\
\hline P5 & $\mathbf{1}$ & $\mathbf{2 . 2 5}$ & $\mathbf{0 . 6}$ & $\mathbf{2 0}$ & $\mathbf{5 0}$ & $\mathbf{1 2 4 0}$ \\
\hline P6 & $\mathbf{1}$ & $\mathbf{2 . 2 5}$ & $\mathbf{0 . 6}$ & $\mathbf{3 0}$ & $\mathbf{5 0}$ & $\mathbf{1 1 5 0}$ \\
\hline P7 & $\mathbf{1}$ & $\mathbf{2 . 2 5}$ & $\mathbf{0 . 6}$ & $\mathbf{4 0}$ & $\mathbf{5 0}$ & $\mathbf{1 1 0 0}$ \\
\hline P8 & $\mathbf{1}$ & $\mathbf{2 . 2 5}$ & $\mathbf{0 . 6}$ & $\mathbf{5 0}$ & $\mathbf{5 0}$ & $\mathbf{8 7 5}$ \\
\hline P9 & $\mathbf{1}$ & $\mathbf{2 . 2 5}$ & $\mathbf{0 . 6}$ & $\mathbf{6 0}$ & $\mathbf{5 0 0 0}$ \\
\hline P10 & $\mathbf{1}$ & $\mathbf{2 . 2 5}$ & $\mathbf{0 . 6}$ & & &
\end{tabular}

* Voulumertric percentages as addition.

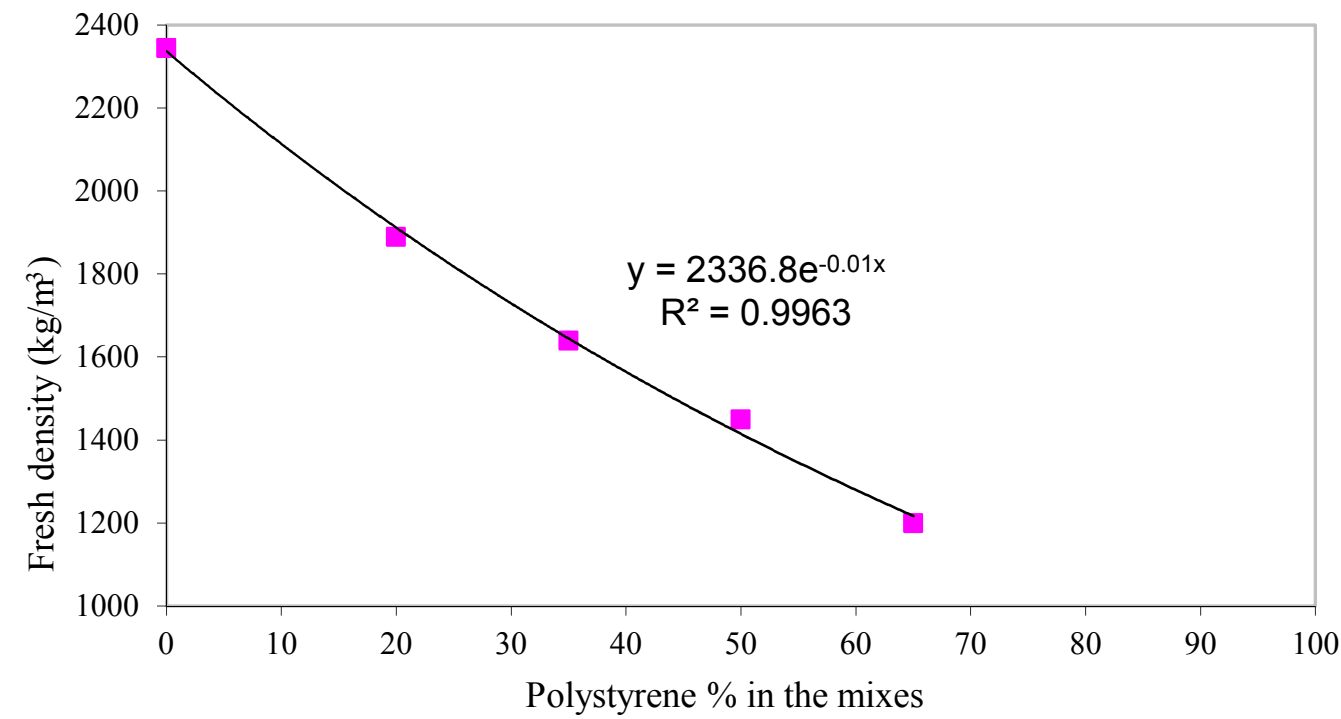

Fig.1 Relationship between density of concrete and Polystyrene percentage

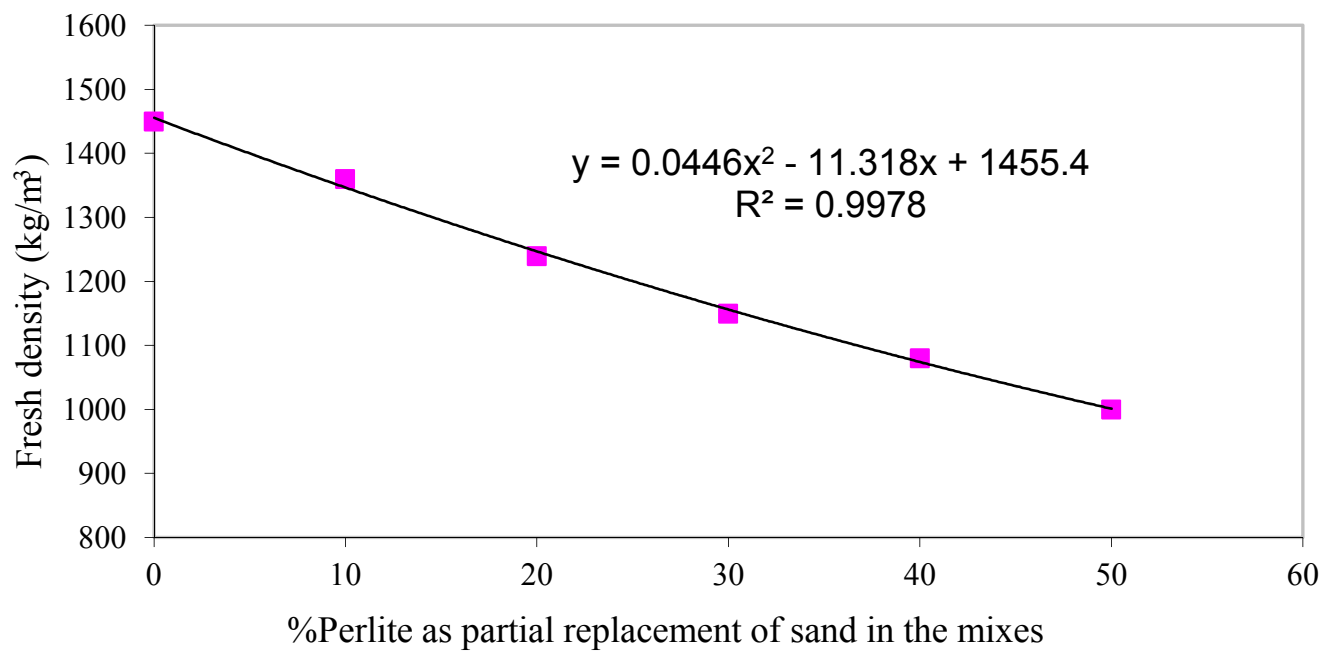

Fig.2 Relationship between density of concrete and perlite percentage as a partial replacement of sand (constant percent of $50 \%$ Polystyrene in the mix). 


\subsection{Compressive strength}

The results of compressive strength at 28 dyas for lightweight concrete mixes are shown in Table 4 . The reduction in compressive strength of concrete with the inclusion of polystyrene beads was found in this regard. Therefore, a significant reduction was recorded by the inclusion of polystyrene as $65 \%$. Such inclusion, decreased the compressive strength from 27.6 $\mathrm{MPa}$ (Ref. Mix) to 6.9 MPa due to the stiffness of polystyrene beads which affects the properties of concrete [6-8]. The relationship between compressive strength of concrete and polystyrene beads is shown in Fig.3.

Besides, the inclusion of perlite with $50 \%$ of polystyrene decreased slightly the compressive strength of lightweight concrete. In this regards, a significant relationship is shown in Fig.4.

Table 4. Mix Proportions and values of compressive strength, flexural strength and absorption.

\begin{tabular}{|c|c|c|c|c|c|c|c|c|}
\hline $\begin{array}{l}\text { Mix } \\
\text { No. }\end{array}$ & \multicolumn{3}{|c|}{ Mix Proportion } & $\begin{array}{c}\text { Perlite, \%a } \\
\text { prtial } \\
\text { replacement } \\
\text { of cement }\end{array}$ & $\begin{array}{l}\text { Polystyrene, } \\
\%\end{array}$ & $\begin{array}{c}\text { Compressive } \\
\text { strength,28days } \\
\text { (MPa) }\end{array}$ & $\begin{array}{c}\text { Flexural } \\
\text { strength } \\
\text { 28days(MPa) }\end{array}$ & $\begin{array}{c}\text { Absorption } \\
\%\end{array}$ \\
\cline { 2 - 9 } Cement & Sand & w/c & & & & \\
\hline P0 & 1 & 2.25 & 0.6 & ---- & 0 & 27.6 & 4.85 & 5.65 \\
\hline P1 & 1 & 2.25 & 0.6 & ---- & 20 & 20.2 & 4.30 & 11.45 \\
\hline P2 & 1 & 2.25 & 0.6 & ----- & 35 & 16.1 & 3.25 & 12.60 \\
\hline P3 & 1 & 2.25 & 0.6 & ---- & 50 & 11.8 & 2.75 & 13.40 \\
\hline P4 & 1 & 2.25 & 0.6 & ---- & 65 & 6.9 & 1.75 & 15.30 \\
\hline P5 & 1 & 2.25 & 0.6 & 10 & 50 & 10.9 & 2.45 & 13.80 \\
\hline P6 & 1 & 2.25 & 0.6 & 20 & 50 & 10.4 & 2.30 & 14.60 \\
\hline P7 & 1 & 2.25 & 0.6 & 30 & 50 & 10.0 & 2.25 & 15.50 \\
\hline P8 & 1 & 2.25 & 0.6 & 40 & 50 & 9.6 & 2.20 & 15.80 \\
\hline P9 & 1 & 2.25 & 0.6 & 50 & 50 & 9.4 & 2.10 & 16.40 \\
\hline P10 & 1 & 2.25 & 0.6 & 60 & 50 & 8.5 & 1.75 & 16.70 \\
\hline
\end{tabular}

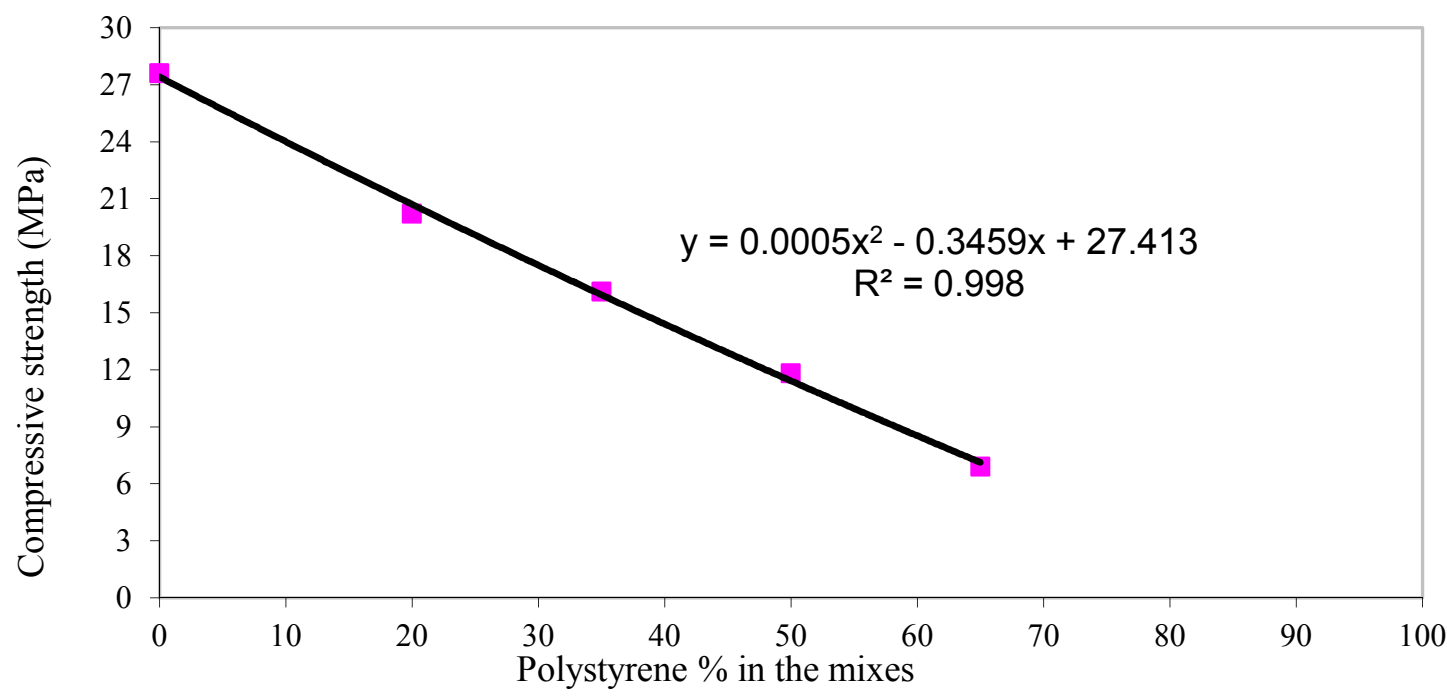

Fig.3 Relationship between compressive strength of concrete and Polystyrene percentage. 


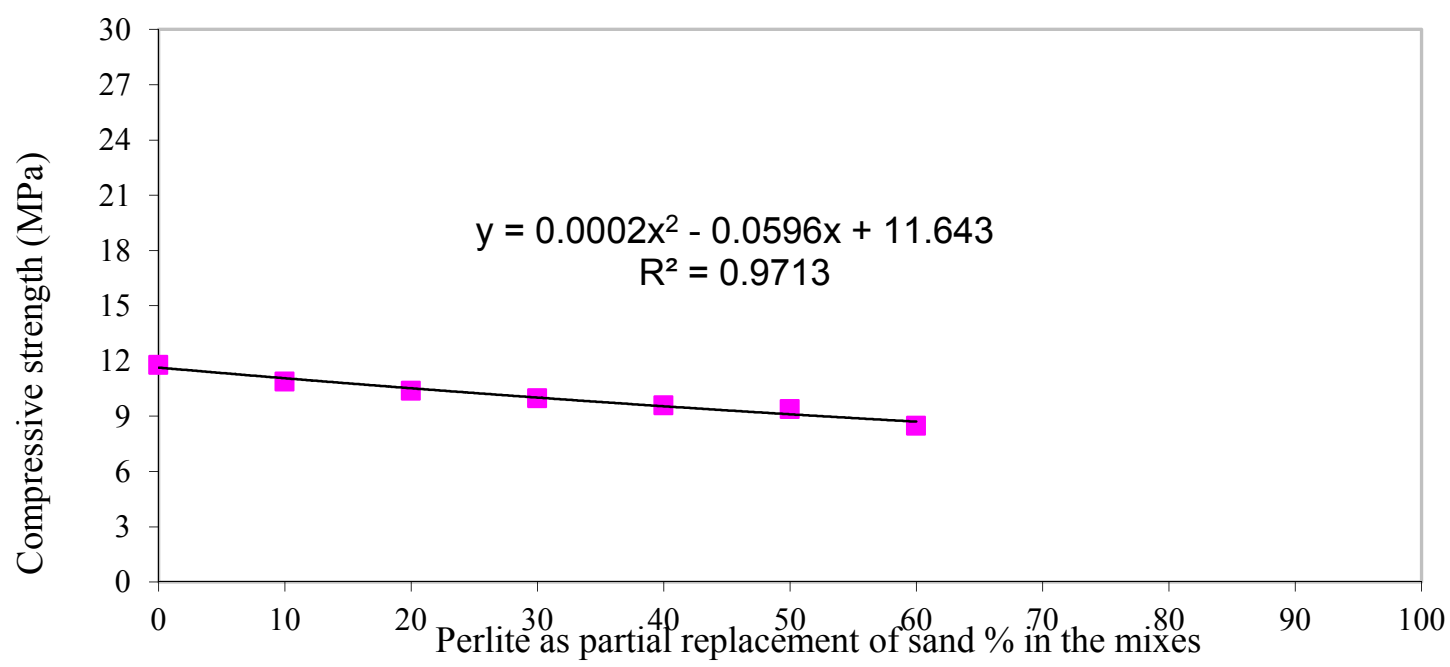

Fig.4 Relationship between compressive strength of concrete and perlite percentage as a partial replacement of sand (constant percent of $50 \%$ Polystyrene in the mix).

\subsection{Flexural strength}

The results of Flexural strength at 28 dyas for lightweight concrete mixes are shown in Table 4. A significant reduction in flexural strength of concrete with the inclusion of polystyrene beads is observed in Fig.5. Therefore, the highest reduction was recorded by the using of polystyrene as $65 \%$. Thus, the flexural strength of concrete was decreased from 4.85 MPa (Ref. Mix) to $1.75 \mathrm{MPa}$ due to such use. This behavior can be attributed to the mechanical properties of polystyrene which affects the properties of concrete [6-8]. Besides, the inclusions of $50 \%$ of polystyrene with different percentages of perlite decrease the flexural strength in the similar manner to that of compressive strength. The relationship between flexural strength of concrete and different percentages of perlite with constant percent of polystyrene "50\%" is shown in Fig. 6.

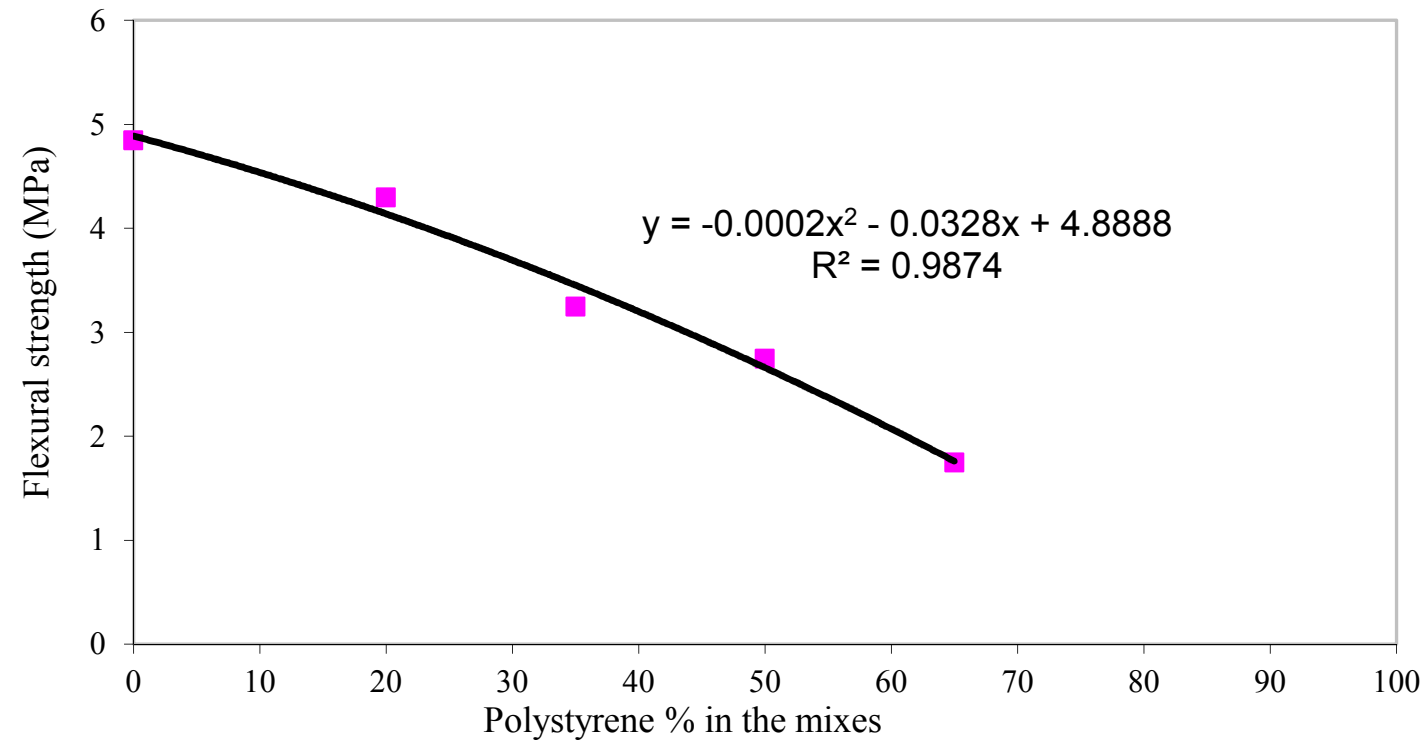

Fig.5 Relationship between flexural strength of concrete and Polystyrene percentage 


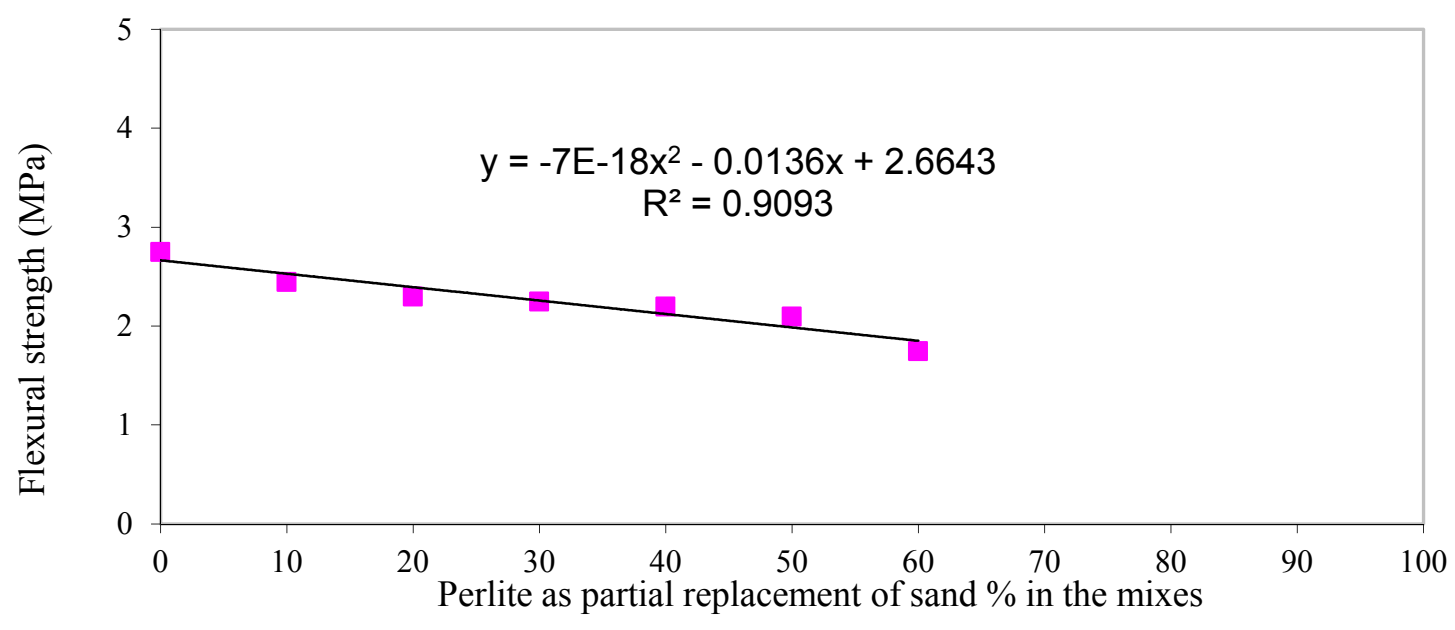

Fig.6 Relationship between flexural strength of concrete and perlite percentage as a partial replacement of sand (constant percent of $50 \%$ Polystyrene in the mix).

\subsection{Absorption}

The results of absorption at 28 dyas for lightweight concrete mixes are shown in Table 4 . The using of polystyrene beads increased the absorption of such concrete. Therefore, the inclusion of $65 \%$ polystyrene increased the absorption from $5.65 \%$ (Ref. Mix) to $16.7 \%$. The relationship between absorption of concrete and polystyrene percentage is shown in Fig.7. The inclusions of $50 \%$ of polystyrene with different percentages of perlite exhibit higher ranges of absorption of the concrete. This behavior can be attributed to the incremental pores in the lightweight concrete mix which are the spaces for the absorbed water [16]. Thus, the relationship between absorption of concrete and different percentages of perlite with constant percent "50 \%" polystyrene beads is shown in Fig. 8.

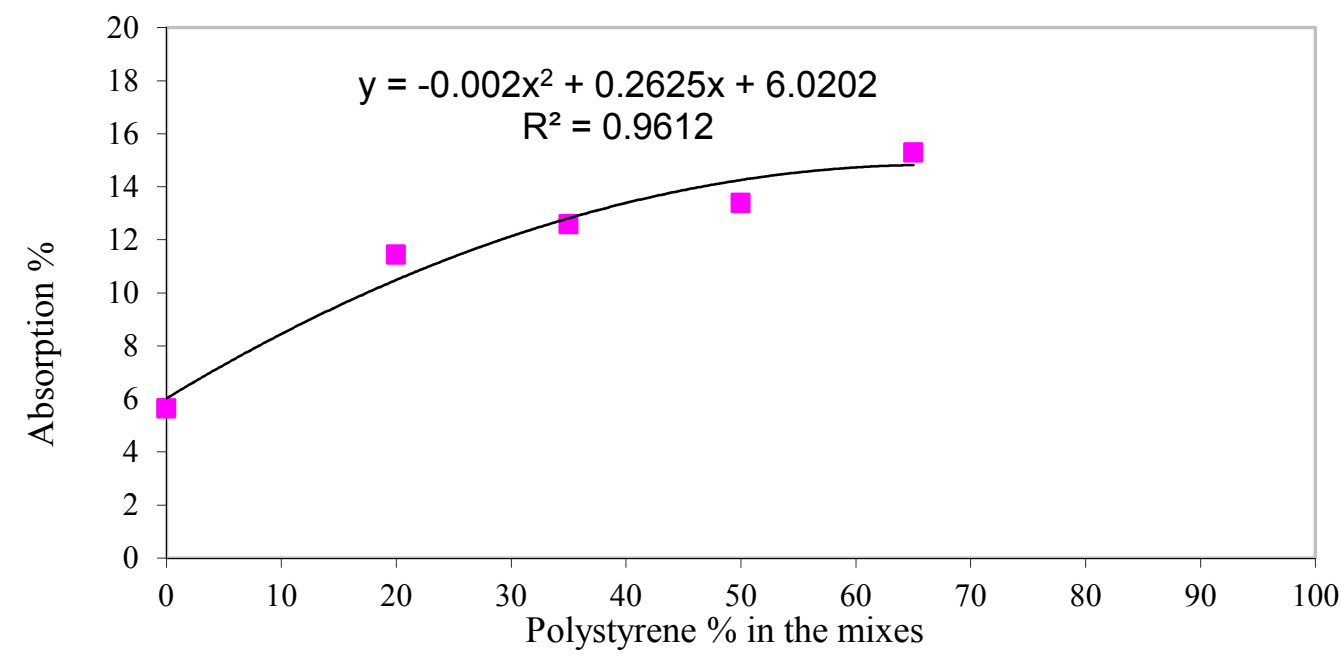

Fig.7 Relationship between Polystyrene percentage and absorption capacity of lightweight concrete 


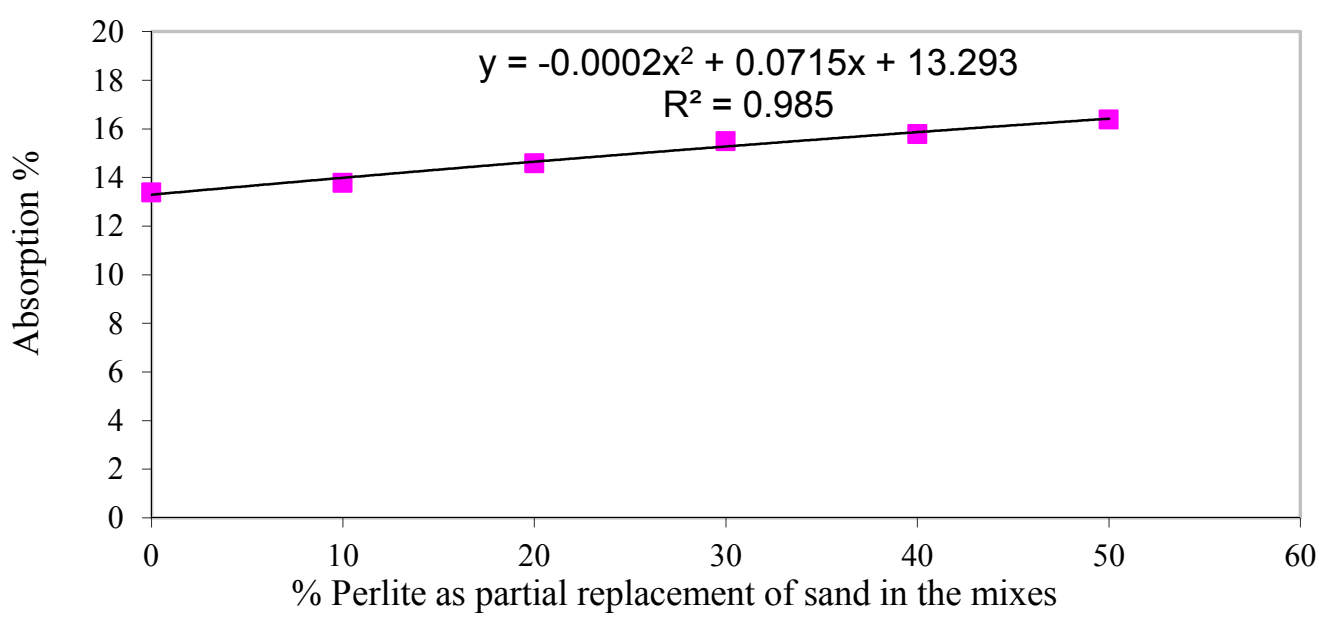

Fig.8 Relationship between perlite percentage as partial replacement of sand $+\mathbf{5 0 \%}$ Polystyrene percentage in the mix with absorption of lightweight concrete

\subsection{Canoe production}

It should be mentioned that the use of $65 \%$ polystyrene was found to be hard to use in concrete mixes. This may be attributed to the disability of the mortar(cement + water + sand) in the mix from maintaining a homogenous mix. In another word, the segregation of polystyrene beads from the mix may occur at this rate of inclusion. However, from the results obtained from different lightweight concrete mixes, it can be found that the mix "P9" with 50\% perlite as partial replacement of sand and 50\% polystyrene as addition in the mix gives the suitable results to produce the canoe from such mix. However, the result of absorption shows that this percentage is $16.4 \%$. This range of absorption is accepted for lightweight concrete when such concrete is not exposed to aggressive salts existed in water. But in case of canoe production, it should be remembered that such canoe may face deteriorations due to chlorides and sulfates found in water. Therefore, the use of water-proofing materials may solve this problem and the result of absorption is reduced to $1.4 \%$ only.

The design of canoe was used depending on some previous researches [17-18]. Thus the details of the dimensions of canoe are shown in Fig.9.

However, a Canoe was produced using the mentioned mix (P9) and the floating of such canoe was observed clearly as shown in Fig. 10. 

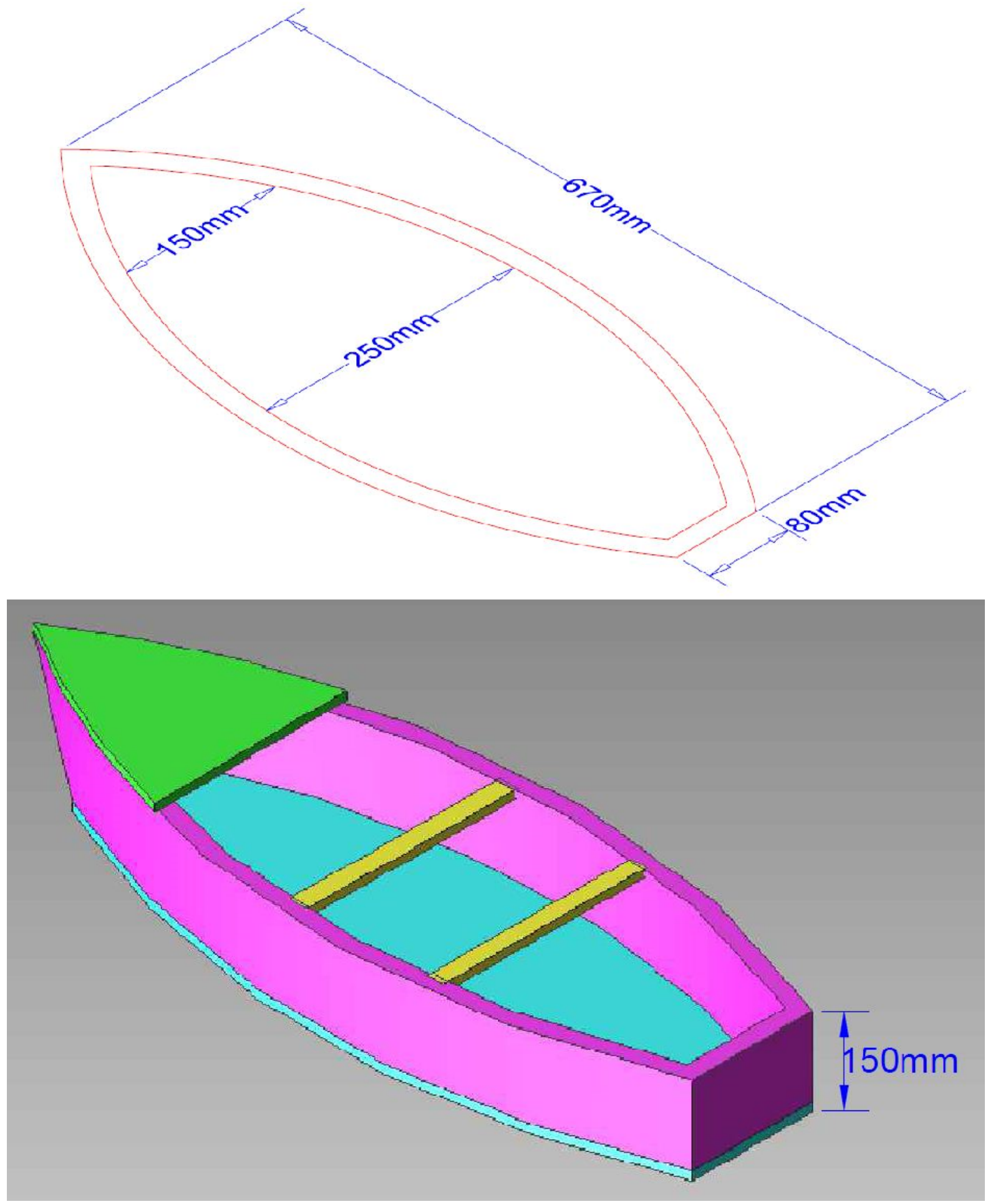

Fig.9 Details of Canoe model and its dimensions. 


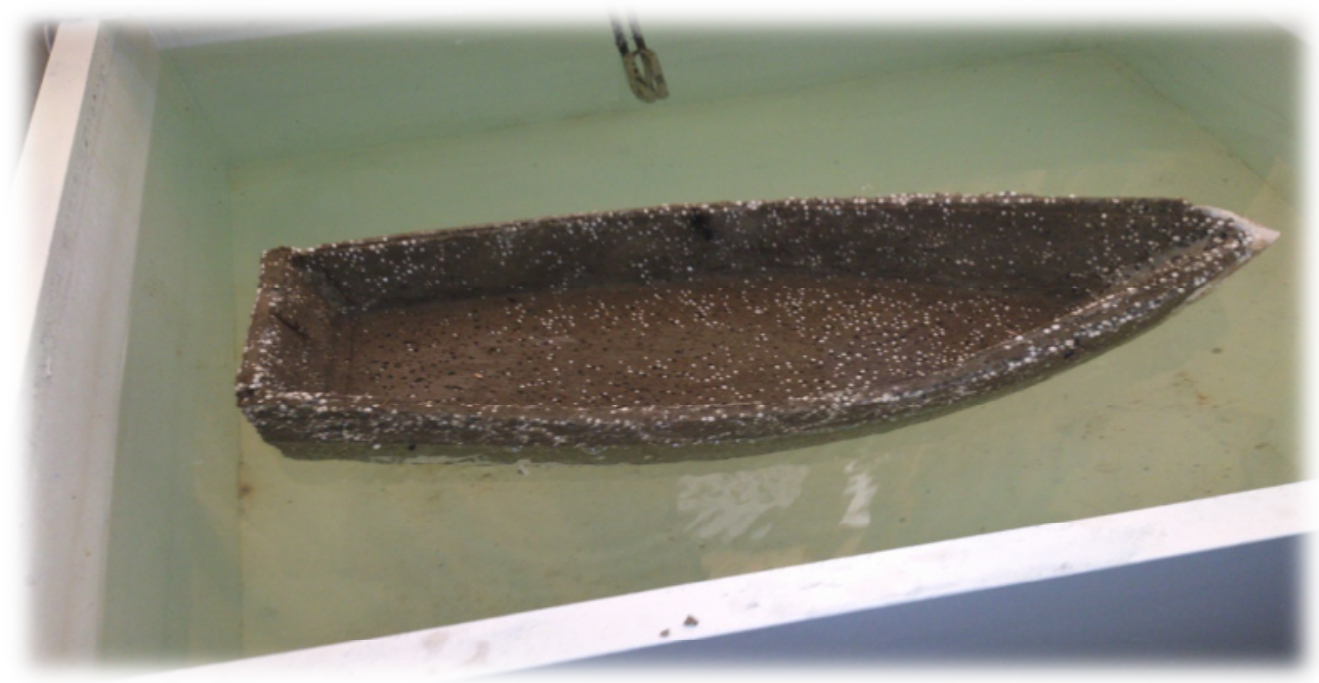

Fig.10. Floating test of produced Canoe.

\section{Conclusions}

Some conclusions can be drawn from this study:

1- The density of lightweight concrete decreased by the inclusion of polystyrene beads in the mix. The use of $65 \%$ of polystyrene reduced the density of the concrete by about $50 \%$.

2-The compressive strength of lightweight concrete was influenced due to polystyrene beads inclusion. The addition of $65 \%$ polystyrene reduced the compressive strength from $27.6 \mathrm{MPa}$ to $6.9 \mathrm{MPa}$.

3 - The use of $65 \%$ of polystyrene beads makes the homogeneity of the mix is elusive. Therefore, the use of $50 \%$ of polystyrene as well as, the partial replacement of sand with perlite as $50 \%$ may solve this problem.

4- Using of $50 \%$ polystyrene with $50 \%$ perlite as partial replacement of sand were found to be suitable for the production of canoe.

\section{References}

1. ACI Committee 213R-03. Guide for structural lightweight aggregate concrete. American Concrete Institute, Farmington Hills, MI, 2003.

2. P.H. Bischoff, K. Yamura and S.H. Perry " Polystyrene aggregate concrete subjected to hard impact". Proceeding institute of civil Engineers 89(2), 1989, p. 225-39.

3. B. Chen and J. Liu "Mechanical properties of polymer-modified concretes containing expanded Polystyrene beads." Construction and Building Materials 21(1), 2007, p.7-11.

4. K.B. Ganesh and D. B. Saradhi "Behaviour of lightweight expanded Polystyrene concrete containing silica fume". Cement and Concrete Research 33, 2003, p.755-62.

5. K. Miled , R.L. Roy and K. Sab " Compressive behavior of an idealized EPS lightweight concrete:size effects and failure mode.". Mechanics of Materials 36(11), 2004, p. 1031-46.

6. A.M. Neville "Properties of concrete", Fourth and Final edition,1995.

7. D.J. Cook "Expanded polystyrene concrete. In: Swamy editor." New concrete materials. Concrete technology and design, vol. 1. London: Surrey press, 1983, pp.41-69.

8. A. Benazzouk., O.Douzane , K.Mezreb and M. Que'neudec "Physico-mechanical 
properties of aerated cement composites containing shredded rubber waste " Cement \& Concrete Composite, ISSN 0958-9465; Vol. 28,2006, pp.650-657.

9. N.A. Memon ,S.R. Sumadi and M. Ramli "Lightweight Aerated concrete incorporating Various Percentages of Slag and PFA" Journal of Applied Sciences: vol. 6 (7):,2006, pp1560-1565.

10. Y. Zandi , M. Ghannadi. And M. Husemc "Studying the Effects of Air Entrain Additive on Light Weight Perlite Concrete" Journal of Basic and Applied Scientific Research, 2(5), 2012, pp.5045-5051.

11. R. G. Demirbogar. "The effects of expanded perlite aggregate, silica fumes and fly ash on the thermal conductivity of lightweight concrete". Cement and concrete research. 2003, 33(7), 2003, pp. 723-727.

12. E. T. Dawood and M. Ramli "Proportioning of crushed brick concrete reinforced by palm fibers" Journal of Materials Sciences and Engineering with Advanced Technology, 2(1), 2010, pp.77-95.

13. Iraqi standard specification (1984), "Characteristics of OPC', Central Agency for standardization and quality control", No.5.

14. ASTM C 109/C 109M-99, 1999, Standard test method for compressive strength of hydraulic cement mortars (using 2-in. or [50-mm] cube specimens, annual book of ASTM, standards, vol. 04.01

15. ASTM C 348-02, 2002, Standard test method for flexural strength of hydraulic cement mortar, annual book of ASTM, standards, vol. 04.01 .

16. E. T. Thanon Dawood and M. Ramli " Hollow block concrete units production using superplasticizer and pumicite" AJCE: Australian Journal of Civil Engineering, 6(1), 2010, p. 35-46.

17. ASCE " National Concrete Canoe Competition", Rules and Regulation, American society of civil engineers, 2014.

18. USC " Concrete Canoe Design Report" University of Southern California, 2009.

The work was carried out at the Technical College of Mosul, Mosul-Iraq. 